\title{
Biyogaz Üretimi İçin Ankara'nın Başlıca Organik Atık Kaynakları
}

\author{
Halil ŞENOL ${ }^{1 *}$, Emre Aşkın ELİBOL ${ }^{2}$, Ünsal AÇIKEL ${ }^{3}$, Merve ŞENOL ${ }^{4}$ \\ ${ }^{1 *}$ Giresun Üniversitesi, Genetik ve Biyomühendislik Bölümü, Giresun \\ ${ }^{2}$ Giresun Üniversitesi, Makina Mühendisliği Bölümü, Giresun \\ ${ }^{3}$ Cumhuriyet Üniversitesi, Kimya Mühendisliği Bölümü, Sivas \\ ${ }^{4}$ Bulancak Anadolu Lisesi, İngilizce ögretmenliği Bölümü, Giresun
}

\begin{abstract}
Özet
Biyogaz üretimi enerji kazanımı ve organik atıkları bertaraf edilmesi açısından önemlidir. Bitkisel ve hayvansal organik atık maddeler, biyogaz üretimi açısından oldukça önemli bir yere sahiptir. Dünya genelinde biyogaz üretiminde substrat olarak kullanılan organik atıklar ve endüstriyel atık sular bizim ülkemizde yeterince değerlendirilmemektedir. Ülkemizde tarımsal ve hayvancılık üretimlerinin sürekli olarak artmasıyla bu ürünlerin atıklarda artmaktadır. Aynı şekilde ülkemizde nüfusun sürekli artma eğiliminde olmasıyla organik atık miktarı da artmaktadır. Ülkemizde özellikle başkent Ankara ilinde organik atık potansiyelinin oldukça fazla olması nedeniyle biyogaz üretim potansiyeli dikkat çekmektedir. Bu çalışmada ülke nüfusunun büyük bir kısmını barındıran Ankara ilinin hayvansal atıklar, mutfak atıkları, atık su arıtma tesisi atıkları ve tarımsal atıkları dikkate alınarak bu atıklardan biyogaz üretim miktarı belirlenmiştir. Sonuç olarak bu çalışmada Ankara'da organik atıklardan üretilebilecek teorik biyogaz enerji değeri $\mathrm{m}^{3} /$ gün olarak değerlendirilmiştir. Bununla birlikte hayvansal atıklardan $277.348 \mathrm{~m}^{3} /$ gün, atık su arıtma çamurundan $515.220 \mathrm{~m}^{3} /$ gün, tarımsal atıklardan 38.493 $\mathrm{m}^{3} /$ gün ve mutfak atıklarından $160.380 \mathrm{~m}^{3} /$ gün olarak bulunmuştur.
\end{abstract}

Anahtar kelimeler: Biyogaz, Ankara, Organik atıklar.

\section{Major Organic Waste Sources in Ankara for Biogas Production}

\begin{abstract}
Biogas production is important in terms of energy recovery and elimination of organic wastes. Organic wastes and industrial wastewater used as substrates in biogas production worldwide are not sufficiently evaluated in our country. In our country, agricultural and livestock production continuously increases with organic wastes. Similarly, the population of our country continuously tends to increase, thus the amount of organic waste is also increasing. Biogas production potential attracts attention due to the fact that the potential of organic waste in our country is very high especially in the capital city of Ankara. In this study, the amount of biogas production from these wastes was determined by considering the animal wastes, kitchen wastes, wastewater treatment plant wastes and agricultural wastes of Ankara, which has a large part of the country's population. As a result, the theoretical biogas energy value that can be produced from organic wastes in Ankara was evaluated as $\mathrm{m}^{3} / \mathrm{day}^{\mathrm{in}}$ this study. $277.348 \mathrm{~m}^{3} /$ day from animal wastes, $9.789 .180 \mathrm{~m}^{3} /$ day from waste water treatment sludge, 38.493 $\mathrm{m}^{3} /$ day from agricultural wastes, $160.380 \mathrm{~m}^{3} /$ day from kitchen wastes have been found.
\end{abstract}

Keywords: Biogas, Ankara, Organic Wastes.

*Sorumlu yazar: halilsenol1990@hotmail.com

Geliş Tarihi: 21/09/2017 Kabul Tarihi: 13/10/2017 


\section{Giriş}

Hayatın başlangıcından bugüne kadar olan ve hep olması gereken enerji ihtiyacı, ilk ortaya çıkışından itibaren birçok yol almıştır. İnsanlar ilk zamanlarda kendi yaşamlarını doğal ortamda sürdürürken ihtiyaçlarını da doğal kaynaklardan sağlamışlardır. Kurutma ve ısıtma olaylarında ilk olarak güneş enerjisini kullanmışlardır. Daha sonra insanlar teknolojilerini geliştirerek doğada var olan enerji rezervlerini kullanmaya başlamışlardır. Bu rezervler; kömür, doğal gaz ve petroldür. Günümüzde ise nüfusun artması, sanayinin gelişmesi, kentleşme ve ihtiyaçlardaki çeşitliliğin artması insanlığın enerji ihtiyacını artırmıştır. Daha sonra insanlar doğası gereği üretim, yatırım, zenginleşme ve büyüme gibi bir takım olaylar peşinden koşmaya başlamıştır. Doğal enerji kaynaklarının hızlı ve fazla kullanılmasının sonucu olarak bu enerji kaynaklarının tükenme riski doğmuştur. Böylece hem doğal enerji kaynaklarının fiyatlarının yükselmesi hem de çevreye olan zararları neticesinde insanlar günümüzde yenilenebilir temiz enerji arayışı içerisine girmiştir. Yenilenebilir enerji kaynaklarının doğa ve insanlık için birçok avantajı bulunmaktadır. Bu enerjiler sürekli olarak tekrarlanabilir ve kaynağını sürekli olarak yenileyebilir niteliktedir. Bununla birlikte bu enerji kaynakları çevre dostu olmaları ve ekolojik dengeye katkı sağlamaları açısından doğal enerji kaynaklarına üstünlük kurmalarıdır [1].

Dünya ve ülkemizin nüfusu giderek artmasından dolayı enerji ihtiyacı da sürekli artma eğilimindedir. Enerji tüketimindeki bu artış mevcut olan doğal enerji kaynaklarını da hızla tüketmektedir. Şuanda dünyamız enerji ihtiyacının $\% 29$ kömür, $\% 24,2$ doğal gaz, $\% 32,8$ petrol, $\% 4,5$ nükleer, $\% 6,8$ hidro ve $\%$ 2,7 yenilenebilir enerji kaynaklarından sağlamaktadır [2]. Ülkemizde ise enerji ihtiyacı \%28,5 petrol, \%29,20 kömür, \%32,5 doğal gaz, \%2,8 hidro, geriye kalan \%7 ise yenilenebilir ve diğer enerji kaynaklarından sağlamaktadır [3]. Ülkemiz enerji kullanımı bakımından sınırlı sayıda rezervlere sahiptir ve enerji kullanımının yaklaşık \%60'ını dışarıdan ithal etmektedir. Fakat ülkemiz yenilenebilir enerji kaynakları açısından oldukça zengindir ve yeterince değerlendirilmemektedir. Biyogaz enerjisi ise yenilenebilir enerjiler statüsünde olup ülkemizde oldukça büyük bir potansiyele sahiptir [4]. Türkiye'nin yıllık ortalama biyokütle potansiyeli tahmini olarak 109,4 milyon ton dur. Ülkemiz y1llık olarak ormanlarında atık olan biyokütle ( kabuk, yaprak, yonga, dal vb.) 5-7 milyon ton olduğu belirtilmiştir. Bu da ülkemizin organik atıklar bakımından aşırı zengin olduğunu desteklemektedir [5].

Türkiye'nin enerji tüketimi hızlı ekonomik gelişiminden dolayı sürekli artmaktadır. Türkiye'nin 2000 ve 2015 yılları arasındaki tükettiği enerji 2000 ile 2010 yılları arasındaki tükettiği enerjiden 5 kat fazladır [6]. Buda bize enerji tüketiminin arttığını ispatlamaktadır. Bu nedenle ülkemizin farklı enerji kaynaklarına yönelmesi gerekmektedir. Bu farklı enerji kaynaklarına alternatif bir kaynak biyogazdır. Çünkü biyogaz üretimi için ülkemiz oldukça elverişli ve zengin bir kaynağa sahiptir [7].

Biyogaz üretimi günümüzde yaygın olarak kentsel atık su arıtma tesislerinde ve artan şekilde tarımsal atıklar, hayvan endüstrisi atıkları gibi organik atıkları bertaraf etmek amacıyla kullanılmaktadır [8]. Biyogaz sistemi prosesleri petrokimyasal endüstrilerde yararlı kullanımları giderek artmaktadır. Ancak uygulamalar sonucunda kara ve suda kirlilik oluşturan işletmeleri temizleyecek kadar aktif değildir $[9,10]$. Petrokimyasal atık su artımları dünyada oldukça çeşitli ve karmaşı proseslerdir. Ancak bu proseslerden biyogaz üretimi çevre kirliliğini bertaraf etmesi açısından önem kazanmaktadır [11].

\subsection{Biyogaz}

Biyogaz içerisindeki gaz bileşimi yüzde hacimsel olarak ortalama; \% 65 metan gazı $\left(\mathrm{CH}_{4}\right)$, \% 35 karbondioksit gazı $\left(\mathrm{CO}_{2}\right)$, \% 0,1-1 azot gazı $\left(\mathrm{N}_{2}\right)$, \% 0,01-0,2 oksijen gazı $\left(\mathrm{O}_{2}\right)$ ve 10-4000 ppm hidrojen sülfür gazı $\left(\mathrm{H}_{2} \mathrm{~S}\right)$ bulunmaktadır. Biyogaz karışımının içerisinde bulunan $\mathrm{H}_{2} \mathrm{~S}$ kullanılan materyalin çeşitliliğine göre değişlik göstermektedir. $\mathrm{H}_{2} \mathrm{~S}$ yüksek oranda reaktif bir madde olduğu için reaktöre aktarım sırasında konsantrasyonu düşme eğilimi göstermektedir. $\mathrm{Bu}$ nedenle substrat hazırlama esnasında olabildiği kadar reaktöre yakın bir yerde hazırlamak gerekir. İçerdiği metan gazı, biyogazın 1sıl değerini oluşturan ana maddedir. $1 \mathrm{~m}^{3}$ biyogazın sağladığı $1 \mathrm{~s} 1$ miktarı 4700-5700 
kcal'dir. Bu değer; 0,62 litre gaz yağı 1,46 kg odun kömürü, 3,47 kg odun, 0,43 kg bütan gazı, 12,3 $\mathrm{kg}$ tezek ve 4,70 kwh elektrik enerjisi eşdeğerindedir. $1 \mathrm{~m}^{3}$ biyogaza eşdeğer yakıt miktarları ise 0,66 litre motorin 0,75 litre benzin $0,25 \mathrm{~m}^{3}$ propan tarafindan sağlanan enerjiye eş değerdir. Biyogaz; temel olarak organik atıklardan kullanılabilir gaz üretilmesini ifade eder. Başka bir deyişle oksijensiz ortamda metanojen bakterilerin uygun $\mathrm{pH}$ ve sicaklıkta organik maddeleri karbondioksit ve metan gazına dönüştürmesidir [12].

Biyogaz sonucu açığa çıkan $\mathrm{CH}_{4}$ gazı ideal bir gazdır. Düşük basınçlarda LPG gibi sıvılaştırılamaz. Sıvılaştırılması için 280-350 bar basınç gerekmektedir. Oksijensiz fermantasyon organik materyallerin oksijensiz ortamda yaşayabilen bakteriler tarafindan bozunması olayıdır. Bu bozunma sonucu hem biyogaz hem de organik gübre elde edilmektedir [13]. Biyogaz, biyokütlenin işlenmesi sonucunda elde edilen yanıcı bir gazdır. Biyogaz, yanıcı diğer gazlardan (örneğin doğalgaz) farklı olarak sadece hayvansal veya bitkisel, yani organik hammaddelerden elde edilmektedir. Bu nedenle saflaştırılmış bir biyogaz doğal gaz enerjisinin yerini tutmaktadır. Biyolojik atıklar, gıda sanayii kaynaklı organik atıklar, organik mutfak atıkları, mısır veya şeker pancarı gibi enerji bitkileri ile hayvan besiciliğinde oluşan hayvansal dışkılar biyogaz tesislerinde substrat olarak kullanılabilir [14].

Biyogaz üretimi genellikle bazı bitki ve hayvan kökenli organik atıklar kullanılmaktadır. Bu atıklar; yemek ve gıda atıkları, bahçe atıkları, tarımsal atıklar, kentsel katı atıklar, hayvan gübreleri ve atıkları, atık su arıtma tesisi atıkları ve bazı endüstriyel atıklar ( deri, tekstil, gıda, orman vb.) dır [15].

Birçok ülkede biyogaz üretimi için biyogaz tesisleri planlanan amaca göre çeşitlilik göstermektedir. Biyogaz üretimi için biyogaz tesisleri kapasitelerine göre de çeşitlilik gösterir. Bu tesislerden $6-12 \mathrm{~m}^{3}$ kapasiteli olanlara aile tipi, 50-150 $\mathrm{m}^{3}$ kapasiteli olanlara çiftlik tipi, $100-200 \mathrm{~m}^{3}$ kapasiteli olanlara ise köy tipi biyogaz tesisi denilmektedir. Fakat Almanya, Danimarka, İsveç ve Amerika gibi ülkelerde $1.000-10.000 \mathrm{~m}^{3}$ kapasiteli sanayi tipi biyogaz tesisleri işletilmektedir [16]. Biyogaz oluşumunda tesis verimi; katı madde oranı, $\mathrm{C} / \mathrm{N}$ oranı, basınç, karıştırma, $\mathrm{pH}$, sıcaklık, yükleme oranı, toksik maddeler ve bekleme süresi gibi birçok bileşene bağlı olmaktadır. Bu bileşenler tesisin yapısına göre değişiklik göstermektedir [15].

Biyogaz kokusuz, renksiz ve parlak bir mavi renkte yanan 1sıl değeri yüksek olan bir gaz karışımıdır. Daha önceki yapılan çalışmalardan biyogazın bileşimi, ortamın sıcaklığı, gaz içerisindeki su içeriği, atıkların cinsi gibi birtakım faktörlerle değiştiği ortaya çıkmıştır. Biyogaz doğal gazın yerini tutabilen bir gazdır. LPG veya doğal gaz ile çalışan bütün cihazlarda küçük değişiklikler yapılarak rahatlıkla kullanılabilir [17].

Tablo 1. Biyogaz ve diğer gazların özellikleri

\begin{tabular}{lllll}
\hline Yakıt & $\begin{array}{l}\text { Isıl değeri } \\
(\mathbf{k j} / \mathbf{k g})\end{array}$ & Yoğunluk & $\begin{array}{l}\text { Hava-yakıt } \\
\text { oranı }(\mathbf{k g} / \mathbf{k g})\end{array}$ & $\begin{array}{l}\text { Ateşleme } \\
\text { sıcaklığı }\left({ }^{\mathbf{0}} \mathbf{C}\right)\end{array}$ \\
\hline Metan & 50000 & $0,72 \mathrm{~kg} / \mathrm{Nm}^{3}$ & 17,2 & 650 \\
Propan & 46300 & $2,02 \mathrm{~kg} / \mathrm{Nm}^{3}$ & 15,6 & 470 \\
Bütan & 45600 & $2,70 \mathrm{~kg} / \mathrm{Nm}^{3}$ & 15,6 & 365 \\
Benzin & 43000 & $0,75 \mathrm{~kg} / 1$ & 14,8 & 220 \\
LPG & 46000 & $0,54 \mathrm{~kg} / 1$ & 15,5 & 400 \\
Motorin & 42500 & $0,85 \mathrm{~kg} / 1$ & 14,5 & 220 \\
Doğal Gaz & 57500 & $0,83 \mathrm{~kg} / \mathrm{Nm}^{3}$ & 17,0 & 600 \\
Biyogaz $\left(\% 60 \mathrm{CH}_{4}\right.$, & & & 650 \\
\%40 CO & & & 10,2 & \\
\hline
\end{tabular}

Yukarıdaki Tablo 1 de biyogaz ve diğer bazı gazların özellikleri verilmiştir. Tabloyu incelediğimizde biyogazın diğer yanıcı gazlara benzer özellikte olduğu görülmektedir [13]. 


\subsection{Biyogaz Üretiminin Mikrobiyolojisi}

Biyogaz oluşumu organik materyallerin oksijensiz fermantasyonu sonucunda oluşan ve içerisinde çoğunlukla $\mathrm{CH}_{4}, \mathrm{CO}_{2}$ gazları bulunan ve hidrojen, azot gazı ve hidrojen sülfür içeren bir gaz karışımından oluşmaktadır. Organik maddelerin oksijensiz ortamda parçalanması ile oluşan biyogaz karışık ve çeşitli mikrobiyolojik flora tarafından sağlanmaktadır [18]. Oksijensiz fermantasyon sonucu oluşan biyogaz üç farklı aşamada gerçekleşir. Bu aşamalar;

- Fermantasyon ve Hidroliz: Organik maddeler hidrolitik ve fermantatif bakteriler tarafindan parçalayarak asetik asit, uçucu organik bileşenler ve karbondioksit oluşturmaktadır.

- Asetik asit oluşumu: Fermantasyon ve hidroliz aşaması sonucunda çıkan ve uçucu yağ asitlerini bir takım bakteri grupları asetik aside dönüştürür.

- Metan gazı olușumu: Oksijensiz fermantasyonun son aşamasıdır. Bu aşamada metan bakterileri, asetik asit oluşumu aşamasında oluşan ürünleri metan, karbondioksit ve su gibi ürünlere dönüştürür. Bu aşamanın sonucunda biyogaz oluşumu tamamlanır [19].

\subsection{Türkiye'de Biyogaz}

Türkiye'de biyogaz üretimi ile ilgili ilk çalışmalar 1957 yılında Toprak ve Su Araştırma Enstitüsünde başlamıştır. 1960'larda bazı çalışmalar yapılarak Devlet Üretme Çiftliklerinde pilot tesisler kurulmuştur. Bunun sonucu olarak Tarım Bakanlığına bağlı olarak 1963 y1lında başlatılan çalışmalarda 5 tanesi Eskişehir Toprak Su Araştırma Enstitüsüne, 2 tanesi Eskişehir'in köylerinde biride çorum deneme istasyonunda olmak üzere toplam 8 adet biyogaz tesisi kurulmuştur. Bu tesislerin bir kısmından verimli bir kısmından verimsiz sonuçlar alınmışır. Buna rağmen yönetimlerin biyogaz üretimine sıcak bakmamaları, teknik eleman bulunmaması, çiftçilerin yeterince eğitilmemesi gibi nedenlerden dolayı çalışmalara son verilmiştir. Ancak 1980 sonrasında UNICEF'in hem finansal hem de teknik bilgi yönünden desteklediği biyogaz üretim çalışmaları DPT tarafından başlatılmıştır. İlk çalışmalar Muş-Alparslan Devlet Üretme Çiftliğinde $35 \mathrm{~m}^{3}$ lük bir tesis kurularak başlamıştır. 1982 yılında konuyla iliği sorumluluk Toprak Su Araştırma Enstitüsüne verilmiş ve devletin köylülere sağladığı krediyle $6,8,12$ ve $50 \mathrm{~m}^{3}$ lük olmak üzere toplam 1000'e yakın biyogaz tesisi kurulmuştur. 2000'li yıllarda ise biyogaz üretimi çalışmalarına özellikle üniversitelerin önderlik ettiği araştırma projeleri olmuştur [13]. 2010 yılında ise Türkiye Cumhuriyeti Çevre ve Şehircilik Bakanlığ ile Almanya Çevre, Doğa Koruma ve Nükleer Güvenlik Bakanlığı ile yapılan bir biyogaz tesisi için imzalar atılmıştır. 1200 baş hayvancılık yetiştirilen tesiste biyogaz üretimi için gerekli tesisin bütün enerji ihtiyacının karşılanacağı belirtilmiştir. Aynı zamanda biyogaz üretimi sonucunda fermente olan gübre, tesisin çiftlik arazilerinde bitki yetiştirmek için gerekli yeterliliği karşıladığını vurgulanmıştır. Ülkemizde diğger biyogaz tesisleri olarak 5 adet $15 \mathrm{~m}^{3}$ lük ve 2 adet $22 \mathrm{~m}^{3}$ lük tesis Kayseri'de, $15 \mathrm{~m}^{3}$ lük 1 adet Konya'da, $22 \mathrm{~m}^{3}$ lük 1 adet gediz gölcük köyünde ve $280 \mathrm{~m}^{3}$ lük 1 adet Elazı̆g'da bulunmaktadir [20].

\subsection{Ankara'da Biyogaz}

Ankara'da 2016 yılında Elmadağ ilçesinde 6 MW' lık bir biyogaz üretim tesisi kurulacağına dair anlaşmalar imzalanmıştır. Tesisin yaklaşık 196.700 metre karelik arazi üzerine kurulacağ planlanmaktadır. Proje maliyeti olarak 54.810.980 TL hesaplanmıştır. Bu proje kapsamında Elmadağ ve Akyurt ilçesinde biyogaz üretiminde hayvan gübrelerinden faydalanılacaktır. Bu hayvanlar ağırlıklı olarak büyükbaş hayvan, hindi ve tavuktur. Proje kapsamında biyogaz tesisine günde 800-1200 ton taze büyükbaş hayvan gübresi, sebze ve meyve artıkları, tavuk ve hindi gübreleri kullanılabilecektir. Üretimin sonucunda yan ürün olarak organik gübre üretileceği belirtilmiştir [21].

2014 yılında Ankara'nın Beypazarı ilçesine kurulan bir biyogaz tesisi tavuk gübresi kullanarak metan biyogaz üretmeye başlamışırır. Kurulan tesiste saatte 2,5 MW elektrik enerjisi üretilmiştir. Bu üretimin yanında 1s1 ve organik gübre üretildiği belirtilmiştir [22]. 
Ayaş ilçesinde 2017 yılında Invest Trading Consulting- Katı atık (ITC-KA) Enerji tesisi tarafından sunulan organik ve mekanik atıklardan elektrik üretilmek üzere kurulacak olan $250 \mathrm{MW}$ ' lik bir tesis halkın görüşüne sunulmuştur [23].

\section{Materyal ve Metot}

Biyogaz üretimi gerçekleştirilirken birçok organik madde kullanılır. Bu maddeler; hayvansal atıklar, bitkisel atıklar, organik atık içeren mutfak atıkları, şehir ve endüstriyel atıklardır. Biyogaz üretimi yapılırken üretim tesisinde bazı teknik özelliklere dikkat edilmelidir. Çünkü teori ile uygulama her zaman aynı sonucu vermeyebilir. Bunun için bir biyogaz üretim tesisinin ekonomik açıdan uygun olabilmesi için ne kadar miktarda organik atık madde miktarına gerek olduğunu, işletme büyüklüklerini, işletme tiplerini dikkate alarak potansiyel hesaplamaları yapmak gerekmektedir [24].

Biyogaz üretim potansiyeli belirlenirken Ankara ilinin 2017 yılında toplam atık su arıtma tesisi atıkları, tarımsal atıkları, mutfak atıkları ve toplam hayvan atıkları dikkate alınarak yapılacaktır.

Tablo 2. Bazı organik atıkların biyogaz verimi

\begin{tabular}{lcc}
\hline \multicolumn{1}{c}{ Organik madde cinsi } & $\begin{array}{c}\text { Biyogaz verimi }\left(\mathbf{m}^{\mathbf{3} /}\right. \\
\text { ton) }\end{array}$ & Kaynak \\
\hline Katı sığır gübresi & 45 & {$[25]$} \\
Mutfak atıkları & 30 & {$[26]$} \\
Küçükbaş hayvan gübresi & 60 & {$[19]$} \\
Kümes hayvanı gübresi & $70-90$ & {$[27]$} \\
Attk su arıtma çamuru & $310-800$ & {$[13]$} \\
Yemek atıkları & $50-480$ & {$[26]$} \\
Sebze ve meyve atıkları & $45-110$ & {$[25]$} \\
Tarımsal atıklar & 20 & {$[27]$} \\
Kanatlı gübresi & $310-620$ & {$[19]$} \\
Șeker pancarı küspesi & 147,1 & {$[28]$} \\
\hline
\end{tabular}

Yukarıdaki Tablo 2 de bazı organik atıkların ton başına biyogaz üretim değerini vermiştir [25,26].

Tablo 2 verilerine baktığımızda ton başına mutfak atıklarından ortalama $30 \mathrm{~m}^{3}$,tarımsal atıklardan 20 $\mathrm{m}^{3}$ ve atık su arıtma çamurundan en az $310 \mathrm{~m}^{3}$ biyogaz üretildiği vurgulanmıştır.

\subsection{Ankara'nın Tarımsal Atıkları}

Ankara'da tarım alanı birçok tarla ürünlerine dayanmaktadır [29]. Ankara geniş ekim alanına sahiptir. Buğdaydan başka, yulaf, arpa, baklagiller, sanayi bitkileri, şeker pancarı, yumru bitkiler, sebze ve meyve çeşitleri, patates gibi ürünler yetişmektedir. Sakarya ve buna dökülen akarsuların vadilerinde pirinç ekilir. Armudu ve üzümü Ankara'da meşhurdur. Polatll, Haymana, Ş. Koçhisar, Bala ve Çubuk'ta buğday ekimi yaygındır. Arpa, yulaf, şekerpancarı, kavun, karpuz ve sebze üretimi de tarımda önemli yer tutar. Meyvecilik pek yaygın değildir, fakat armut, elma, kayısı, kiraz, vişne, erik ve ceviz gibi meyveler yetiştirilir. En çok yetiştirilen meyve ise üzümdür. Üretilen bu ürün miktarları aşağıdaki Tablo 3. de verilmektedir. 
Tablo 3. Ankara'nın 2015 yılında tarımsal ürün miktarı

\begin{tabular}{ll}
\hline Tarımsal ürün & Miktarı (ton) \\
\hline Buğday & 1.150 .555 \\
Arpa & 688.728 \\
Şeker pancarı & 475.070 \\
Misır & 226.916 \\
Ot & 209.996 \\
Soğan & 322.604 \\
Kavun & 165.259 \\
Kimyon & 9.306 \\
Karpuz & 111.178 \\
Havuç & 127.750 \\
Domates & 118.998 \\
Armut & 15.663 \\
Üzüm & 28.590 \\
Vişne & 18.732 \\
Elma & 31.200 \\
Toplam & $\mathbf{3 . 7 0 0 . 5 4 5}$ \\
\hline
\end{tabular}

Yukarıdaki Tablo 3 de Ankara ilinin toplam tarımsal ürün miktarları verilmiştir. Ankara' da toplam tarım arazi alanı 12.241.704 dekardır [30,31].

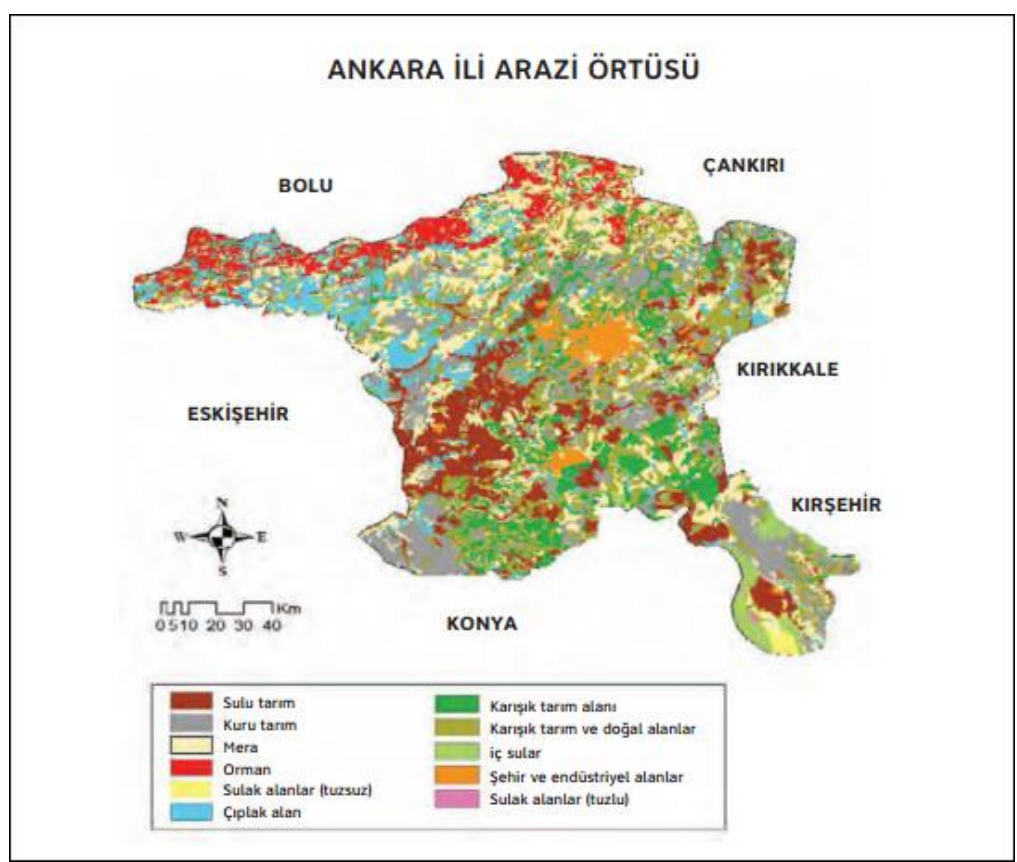

Şekil 1. Ankara ilinin yüzölçümüne göre tarım alanları

Ankara'da üretilen tarımsal ürünlerin coğrafi dağılımı yukarıdaki Şekil 1 de verilmiştir. Şekil 1 den anlaşıldığı üzere Ankara'nın tarım alanları neredeyse her yerinde mevcuttur. Tarımsal üretimde en fazla y1llık 1.150.555 ton üretimle buğday gelmektedir. 
Tablo 4. Ankara'da en çok yetişen tarla bitkilerinin organik atık miktarı

\begin{tabular}{lc}
\hline Tarımsal Bitki & $\begin{array}{c}\text { Organik Atık Miktarı } \\
\text { (Kg/ Dekar) }\end{array}$ \\
\hline Buğday & 37 \\
Arpa & 36 \\
Çavdar & 37 \\
Ayçiçeği & 86 \\
Şeker pancarı & 87 \\
Ortalama değer & $\mathbf{5 6 , 6}$ \\
\hline
\end{tabular}

Yukarıdaki Tablo 4 de bazı tarımsal ürünlerin dekar başına ürettikleri organik atıkların değerleri belirtilmiştir [27]. Yukarıdaki Tablo 4 de Ankara'da en çok yetişen bitkilerin dekar başına atık miktarı $\mathrm{kg}$ cinsinden verilmiştir. Tarımsal atıklardan biyogaz üretimi hesaplamaları yapılırken dekar başına ortalama değer olan $56,6 \mathrm{~kg}$ atık dikkate alınacaktır.

\subsection{Ankara'nın Mutfak Atığı}

Günümüzde her evde tüketim sonucunda bazı organik atıklar oluşmaktadır. Oluşan bu organik atıklar çöpe gönderilir. Çöplerde biriken bu atıklar yer kaplaması ve koku gibi birtakım çevre problemleri yaramaktadır. $\mathrm{Bu}$ organik atıklar çöpe gönderilme yerine evde biriktirilmesiyle gaz üretiminde kullanılarak çevreye ve ev bütçesine katkı sağlanabilir [32].

Bir yörenin mutfak atığı hesaplanan verilere göre kişi başına mutfak atık değeri yaklaşık $1 \mathrm{~kg}$ dır [26].Bu atığın \% 60’ı organik atıktır. Ankara'nın toplam 2017 nüfusu 5.346.518'dir [33]. Bu verilere göre toplam mutfak atıklarından elde edilebilecek sonuçlar rahatlıkla hesaplanabilmektedir. Toplam mutfak atık potansiyeli yaklaşık olarak 5,346 megatondur.

Ankara'da kentsel katı atıkların değerlendirilmesine yönelik bazı bölgelerde ve ilçelerde biyogaz üretimi yapılmakta ancak bu atıklar yeterince değerlendirilmemektedir. Mamak çöplüğüne kurulan bir biyogaz tesisi 38,6 MW/saat elektrik üretmektedir [34]. Bu üretim ile Ankara ilinin elektrik ihtiyacının \%7 si karşılanmaktadır. Ancak Ankara'nın bütün ilçelerindeki çöplükler bu potansiyele sahiptir.

\subsection{Ankara'nın Atık su Arıtma Çamuru Potansiyeli}

Biyogaz üretimi amaçlı kullanılan organik maddelerden biride atık su arıtma çamurudur. Atık su endüstriyel, kentsel, tarımsal ve diğer kullanımlar sonucu kirlenmiş ve özellikleri kısmen değişmiş sudur. Atık su arıtma çamuru yüksek miktarlarda organik madde, besin maddeleri ve patojen bakteriler içermesi nedeniyle atık suların arıtılması önem kazanmaktadır. Atık su arıtma çamurunun 1sıl değeri çamurun tipine ve içerdiği organik madde miktarına bağlıdır. Evsel atık su arıtma tesisinde kişi başı gaz miktarı 15-22 litre/ kişi.gün olarak değişmektedir. Oluşan gazın metan yüzdesi \% 65 olup enerji değeri $22,4 \mathrm{MJ} / \mathrm{m}^{3}$ 'dür [35].

Örnek olarak atık su arıtma tesisinde dekantöre giren çamurun büyük bir kısmı su olup, Kuru Madde Miktarı (KMM) tipik olarak \% 1-5 arasındadır [36]. Bu değerin ortalaması alınırsa \%3 diyebiliriz. Belediye arıtma tesisleri genel olarak 100 litre kanalizasyon suyunu 1-2 litrelik çamura çevirerek artıma yaparlar. Kirlenmeye sebep olan maddelerin sudan alınmasıyla oluşan geriye kalan kısım atık çamurdur. Diğer organik atıklardan farklı olarak bu atıkların yok edilmesi veya bertaraf edilmesi çok zordur ve pahaliya gelmektedir [37]. 
Tablo 5. Ankara'da Atıksu arıtma tesisleri ve kapasiteleri

\begin{tabular}{ll}
\hline Atıksu arıtma tesisi & $\begin{array}{l}\text { Kapasitesi } \\
\left(\mathbf{m}^{3} / \mathbf{g u ̈ n}\right)\end{array}$ \\
\hline Tatlar Atık Su Arıtma Tesisi & 765.000 \\
Çubuk Atık Su Arıtma Tesisi & 19.200 \\
Karaköy Atık Su Arıtma Tesisi & 42.000 \\
Kalecik Atık Su Arıtma Tesisi & 2.500 \\
Ayaş-Sinanlı Atık Su Arıtma Tesisi & 6.500 \\
Elmadağ Atık Su Arıtma Tesisi & 8.700 \\
Kahraman Kazan Atık Su Arıtma Tesisi & 10.300 \\
Paket Atık Su Arıtma Tesisleri & Değişken \\
Hasan Oğlan Atık Su Arıtma Tesisi & 3.000 \\
Lalahan Atık Su Arıtma Tesisi & 1.500 \\
Toplam & $\mathbf{8 5 8 . 7 0 0}$ \\
\hline
\end{tabular}

Yukarıdaki Tablo 5 de gösterildiği üzere Ankara'da toplam günlük en az $858.700 \mathrm{~m}^{3}$ su arıtılmaktadır. [38]. Atık su arıtma tesisi çamurlarının alternatif kullanım alanları olarak; toprağa serme, yakma, gazlaştırma, depolama ve biyometan oluşturmadır. Bunların en avantajlısı ve en verimlisi olarak biyometan elde edilmesidir.

\subsection{Ankara'nın Hayvancılık Potansiyeli}

Hayvansal atıklar; sığır, at, koyun, keçi, kanatlı hayvan ve domuz gibi hayvanların gübreleri, mezbaha artıkları, hayvansal ürünlerin işlenmesi esasında meydana gelen atıklardır. Biyogaz tesis kurulumları ve projeleri değerlendirilmesi yapılırken önce potansiyel değer hesaplanmalıdır. Bunun için gerekli ön çalışma ilk olarak tesisin hangi organik madde ile çalışacağını tespit etmektir [39]. Bunun için tesiste kullanılacak hayvanın günlük gübresi ve bu gübreden elde edilebilecek biyogaz miktarı hesaplanmalıdır. Günlük ortaya çıkan gübre miktarı hayvanların gübre verimleri cinslerine göre değişik miktarlarda olmaktadır. Gübre miktarları teorik olarak büyük baş hayvanlarda canlı ağırlı̆̆ının günlük \%5-6'sı kadar, küçükbaş hayvanlarda ise canlı ağırlı̆̆ının \%4-5'i kadar ve kanatlı hayvanlarda ise canlı ağırlı̆̆ının \% 3-4'üdür. Ancak hesaplamalarda ortalama değer olarak kabul edilen standartlar ise Tablo 6 da belirtilmiştir [40].

Tablo 6: Bir adet hayvan cinsinin yaş gübre miktarları ve biyogaz potansiyelleri

\begin{tabular}{lcc}
\hline Hayvan cinsi & $\begin{array}{l}\text { Yaş gübre } \\
\text { miktarı } \\
\text { (ton/yı) }\end{array}$ & $\begin{array}{l}\text { Biyogaz verimi } \\
\left(\mathbf{m}^{\mathbf{3}} / \mathbf{t o n}\right)\end{array}$ \\
\hline Büyükbaş hayvan & 3,6 & 33 \\
Küçükbaş hayvan & 0,7 & 58 \\
Kanatlı hayvan & 0,022 & 78 \\
\hline
\end{tabular}

Hayvan gübresinden dikkat edilmesi gereken diğer durumlardan biri ise hayvan gübrelerinin değişik sıcaklıklarda optimum bekleme süreleri ve biyogaz üretim verimidir. Biyogaz üretiminde ortam sıcaklığı önemlidir. Bu sıcaklığın en verimli olduğu değer 30-39 ${ }^{\circ} \mathrm{C}$ 'dir. Isıtma olmadan özellikle kış aylarında sıcaklığın bu değere ulaşması mümkün değildir. Sicaklığın $10{ }^{0} \mathrm{C}^{\prime}$ nin altına düşmesi durumunda biyogaz üretimi durur. Buna göre; optimum sıcaklık korunmadığı takdirde, daha düşük sicaklıklarda biyogaz üretim verimlerinde azalma olduğu görülmektedir [19]. 
Tablo 7: 2016 y1lı Ankara ilinin bazı hayvanların sayısı

\begin{tabular}{lc}
\hline Hayvan cinsi & Hayvan sayısı \\
\hline Sığır & 363.722 \\
Manda & 1.311 \\
Toplam Büyükbaş & $\mathbf{3 6 5 . 0 3 3}$ \\
& \\
Koyun & 991.413 \\
Keçi & 193.891 \\
Toplam Küçükbaş & $\mathbf{1 . 1 8 5 . 3 0 4}$ \\
& \\
Toplam Tavuk & $\mathbf{4 . 8 6 2 . 8 6 2}$ \\
\hline
\end{tabular}

Yukarıdaki Tablo 7 de Ankara'da TÜIK verilerine göre kayıtlı büyükbaş, küçükbaş ve kanatlı hayvan sayısı verilmiştir. Bu verilere göre Ankara'da toplam 6.413.199 tane hayvan vardır [31].

$1 \mathrm{~m}^{3}$ biyogazın değeri yaklaşık olarak 4,7 kwh olarak belirlenmiştir 2016 enerji değeri hesabına göre içerisinde \%55-60 $\mathrm{CH}_{4}$ içeren bir biyogazın $1 \mathrm{~m}^{3}$ değeri ortalama 1,41 TL değerindedir [41].

\section{Bulgular ve Tartıșma}

Tablo 8. Ankara'nın günlük bazı organik atık miktarları

\begin{tabular}{ll}
\hline Organik atık cinsi & $\begin{array}{l}\text { Toplam organik } \\
\text { atık miktarı } \\
\text { (ton/gün) }\end{array}$ \\
\hline Tarımsal Atıklar & 1.924 \\
Mutfak Atıkları & 5.346 \\
Atık su Arıtma Çamuru Atıkları & 858.700 \\
Hayvansal Gübre Atıkları & 6.252 \\
Toplam & $\mathbf{8 7 2 . 2 2 2}$ \\
\hline
\end{tabular}

Yukarıda ki Tablo 8 de Ankara ilinin toplam organik atıkları verilmiştir. Ankara'nın en çok atık potansiyeli atık su arıtma çamurudur.

Tarımsal atıklardan biyogaz üretim potansiyeli hesaplamaları yapılırken önce Ankara'da yetişen buğday, arpa ve şeker pancarı ürünleri için Tablo 4 deki teorik değerler dikkate alınarak hesaplanmıştır. Diğer meyve ve sebze gibi organik atıklarla hesaplama yapılırken ortalama değer dikkate alınmıştır. Ankara'nın toplam tarım alanı 12.241.704 dekardır. Buda toplam yüzeysel alanın $\% 49$ una eşittir [42]. Ankara'nın ortalama dekar başına 56,6 kg organik atık oluşturduğunu kabul edersek, yapılan hesaplamalar doğrultusunda yaklaşık yıllık olarak 692.880 ton tarımsal atık elde edilmektedir. Bu atıkların bir kısmı yakılarak değerlendirilse de diğer kısmı atık olarak çevreye zarar verici niteliktedir. Tablo 2 den verilen bilgilere göre 1 ton tarımsal atıktan $20 \mathrm{~m}^{3}$ biyogaz üretilebileceği vurgulanmıştır. $\mathrm{O}$ halde Ankara'nın tarımsal atıklarından senelik elde edilebilecek biyogaz miktarı teorik olarak: 20 x $692.880=13.857 .600 \mathrm{~m}^{3} / \mathrm{y} 1 \mathrm{l}$ bulunmaktadır. Bu değer de 38.493 $\mathrm{m}^{3} /$ gün biyogaz üretimine denk gelmektedir.

Mutfak atıklarından biyogaz üretimi hesaplamaları yapılırken kişi başına düşen günlük mutfak atık miktarı ortalama $1 \mathrm{~kg}$ kabul edilmektedir. Tablo 2 verilerine göre ortalama 1 ton mutfak atığından 30 $\mathrm{m}^{3}$ biyogaz elde edilmektedir. Ankara'da günlük toplam mutfak atık potansiyeli ortalama 5.346 .518 kg'dır. Bu değer yaklaşık 5.346 ton değerine karşılık gelmektedir. O halde toplam biyogaz üretim miktarı teorik olarak: 5.346 x $30=160.380 \mathrm{~m}^{3} /$ gün' dür.

Atık su arıtma çamurundan biyogaz üretimi hesaplamaları yapılırken atık su hacmindeki ortalama kuru madde miktarı \%1-5 arasında değiştiği vurgulanmıştı. Hesaplamalar yapılırken bu değerin ortalama miktarı \% 3 olarak kabul edebiliriz. Ankara'da her gün ortalama 858.700 ton atık su arıtılmaktadır. Bu atık suyun $858.700 \times 0,03=25.761$ ton/gün atık su arıtma çamuru elde edilir. Tablo 2 verilerine göre 1 
ton atık su arıtma çamurundan toplam $380-800 \mathrm{~m}^{3}$ biyogaz üretilir. Ancak atık su arıtma tesislerinde atık su arıtma çamurundan biyogaz üretimi yapılırken herhangi bir içten 1sıtmalı reaktör kullanılmazsa bu verim yaklaşı \%10 katına düşer. Aynı şekilde deneysel olarak atık su arıtma çamurlarından üretilen biyogaz miktarı teorik değerinden farklı olabilmektedir. Ancak bazı çalışmalarda bir ton arıtma çamuru başına yaklaşık biyogaz verimi $10-30 \mathrm{~m}^{3}$ olmuştur. Ancak bu değeri ortalama $20 \mathrm{~m}^{3}$ almak mümkündür. Bu veriye göre Ankara'da günlük atık su arıtma çamurundan üretilebilecek biyogaz miktarı teorik olarak en az: $25.761 \times 20=515.220 \mathrm{~m}^{3} /$ gün dür.

Ankara'nın hayvancılık atıklarından elde edilebilecek biyogaz miktarı hesaplamalarında Tablo 6 verilerine göre 1 ton yaş gübre başına büyükbaş hayvandan $33 \mathrm{~m}^{3}$, bir küçükbaş hayvandan $58 \mathrm{~m}^{3}$ ve bir kanatlı hayvandan $78 \mathrm{~m}^{3}$ biyogaz elde edildiği vurgulanmıştır. $O$ halde toplam büyükbaş hayvanlardan elde edilebilecek atı miktarı: $3,6 \times 365.033=1.314 .118$ ton/yıl atık elde edilir. Aynı şekilde küçükbaş hayvanlardan senelik: 0,7 x $1.185 .304=829.712$ ton/yıl yaş gübre elde edilir. Aynı şekilde Ankara'da toplam tavuklardan senelik: $4.862 .862 \times 0,022=106.982$ ton/y1l yaş atık elde edilir. $\mathrm{O}$ halde toplam biyogaz potansiyeli büyükbaş hayvanlardan: $1.314 .118 \times 33=43.365 .894 \mathrm{~m}^{3} / \mathrm{y} 1$, küçükbaş hayvanlardan $829.912 \times 58=48.134 .896 \mathrm{~m}^{3} / \mathrm{y} 1$ l, kanatlı hayvanlardan ise $106.982 \times 78=$ $8.344 .596 \mathrm{~m}^{3} / \mathrm{y} 1 \mathrm{l}$ biyogaz elde edilir. Bu verilere göre Ankara ilinde toplam hayvan yaş gübresinden elde edilebilecek biyogaz miktarı: $99.845 .386 \mathrm{~m}^{3} / \mathrm{y} 1 \mathrm{l}$ bulunur. Bu değer yaklaşık olarak 277.348 $\mathrm{m}^{3} /$ gün değerine karşıllık gelmektedir.

Tablo 9. Ankara'nın günlük biyogaz potansiyeli

\begin{tabular}{ll}
\hline Organik attk & Biyogaz potansiyeli $\left(\mathbf{m}^{3} /\right.$ gün $)$ \\
\hline Atık su arıtma çamuru & 515.220 \\
Hayvan gübreleri & 277.348 \\
Mutfak atıkları & 160.380 \\
Tarımsal atıklar & 38.493 \\
Toplam & $\mathbf{9 9 1 . 4 4 1}$ \\
\hline
\end{tabular}

Yukarıda ki Tablo 9 da Ankara ilinin hesaplanan organik atıklardan oluşan biyogaz potansiyeli verilmiştir.

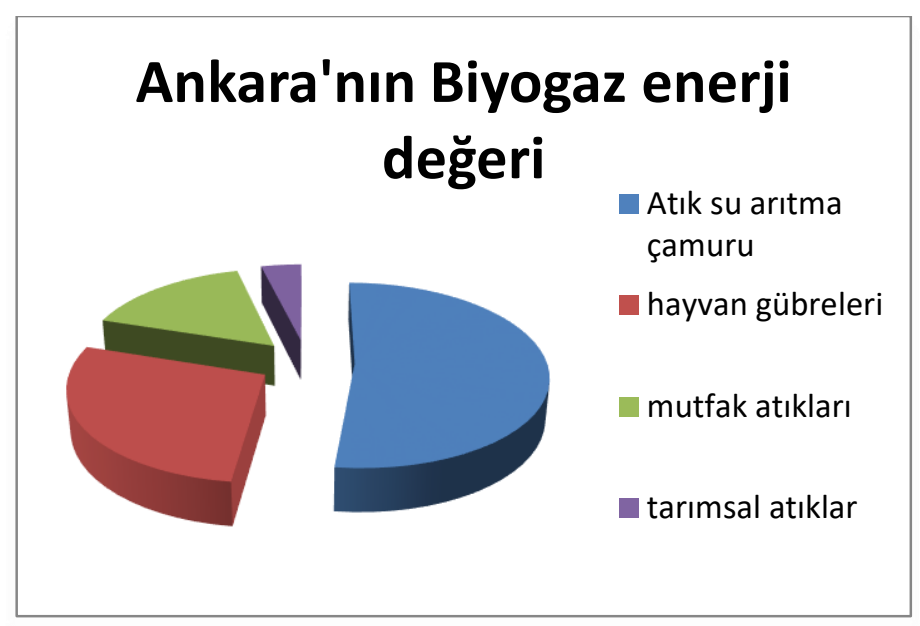

Şekil 2. Ankara’nın bazı organik atıklara göre biyogaz enerji dağılımı

Yukarıda Şekil 2 ye bakıldığında Ankara ilinde en çok biyogaz üretiminin atık su arıtma tesislerinde gerçekleştiği görülmektedir. Bu atıklardan elde edilen biyogaz miktarının enerji getirisini hesaplamak gerekirse atık su arıtma çamurundan: $515.220 \times 1,41=726.460 \mathrm{TL} /$ gün, hayvansal atıklardan 277.348 x $1,41=391.060 \mathrm{TL} /$ gün, mutfak atıklarından $160.380 \times 1,41=226.135 \mathrm{TL}$ ve tarımsal atıklardan ise $38.493 \times 1,41=54.275 \mathrm{TL} /$ gün elde edilir. Toplam 1.397.930 TL/gün kazanılmış olur. 
Tablo 10. Ankara'nın organik atıklardan sağlanabilecek elektrik enerji potansiyeli

\begin{tabular}{ll}
\hline Organik atık & $\begin{array}{l}\text { Elektrik enerji } \\
\text { potansiyeli } \\
\text { (MWh/gün) }\end{array}$ \\
\hline Atık su arıtma çamuru & 2.421 \\
Hayvan gübreleri & 1.303 \\
Mutfak atıkları & 753 \\
Tarımsal atıklar & 181 \\
Toplam & $\mathbf{4 . 6 5 8}$ \\
\hline
\end{tabular}

Yukarıdaki Tablo 10 da Ankara'da bazı organik atıkların biyogaz enerjisinden sağlayabileceği elektrik enerji miktarları verilmiştir. Ankara'nın 1 günlük elektrik enerji miktarı yaklaşık olarak $21.496 \mathrm{MWh}$ $\operatorname{dir}[43]$.

\section{Sonuç ve Öneriler}

Şekil 2 ye bakıldığında Ankara'da bazı organik atıklardan üretilebilecek biyogaz enerji değeri verilmiştir. Sonuçlar kısmına bakıldığında Ankara'da bazı organik atıklardan üretilen toplam biyogaz miktarı $991.441 \mathrm{~m}^{3} /$ gün dür. Bu değer de toplam 1.397.930 TL/gün değerine karşılık gelmektedir. Aynı zamanda Ankara'nın günlük elektrik tüketimi $211.496 \mathrm{MWh}$ olduğu sonuçlar kısmında vurgulanmıştır. Tablo 11 de hesaplanan organik atıkların günlük elektrik enerji kazanc1 ise 4.658 MWh değerindedir. $\mathrm{Bu}$ değer Ankara'nın günlük enerji ihtiyacının yaklaşık \% 21,66'sını karşılamaktadır. Bu değerler göz önünde bulunduğunda Ankara ilinin keşfedilmemiş bir biyogaz enerji değeri vardır. Ankara'da biyogaz üretim tesisleri vardır fakat yeterli değildir. Böylece potansiyeldeki hesaplamalar dikkate alınarak özellikle atık su arıtma tesislerinde biyogaz üretim tesislerinin oluşturulması gerekmektedir.

Biyogaz üretimi yenilenebilir enerji statüsünde bulunmaktadır. Ülkemiz enerji üretimi açısından ürettiği enerjinin yaklaşık 3 katını tüketen bir ülkedir. $\mathrm{Bu}$ nedenle dışa bağımlı bir ülke haline gelmiştir. Bu nedenle özellikle ülke olarak yenilenebilir statüde enerji kaynakları aramamız ve bunun yanında bu kaynaklara verilecek önemi artırmalıdır. Ankara oldukça fazla bir organik atık kapasitesine sahiptir ve bu organik atıkları değerlendirmek ve temiz enerji elde etmek için biyogaz üretimi çalışmalarına önem vermek gerekmektedir.

Organik atıklardan üretilen biyogazın enerji değeri hesaplanırken, yapılan hesaplamalarda maliyet giderleri hariç tutulmuştur. Çünkü maliyet tasarımı tesisin yerine, durumuna ve yıllık kullanımına bağlı olarak değişmektedir. 


\section{Kaynaklar}

1. Yenilenebilir Enerji Kaynağı Olarak Tarımsal Atıklar. 2010. http://www.dektmk.org.tr/pdf/enerji kongresi 11/49.pdf (Erişim tarihi: 24.04.2017).

2. Türkiye Petrolleri Strateji Geliştirme Daire Başkanlığı. 2015. Ham Petrol ve Sektör Raporu, Türkiye.

3. ETKB. 2014. www.enerji.gov.tr (Erişim tarihi: 24.04.2017).

4. Kaya D., Çağman S., Eyidoğan M., Aydöner C., Çoban V., Tırıs M. 2009. Türkiye'nin Hayvansal Atık Kaynaklı Biyogaz Enerjisi ve Ekonomisi, Atık Teknolojileri Dergisi, 1: 48-51.

5. Sümer S.K., Kavdır Y., Çiçek G. 2016. Türkiye'de Tarımsal ve Hayvansal Atıklardan Biyokömür Üretim Potansiyelinin Belirlenmesi, KSÜ Doğa Bilimleri Dergisi, 19 (4): 379-387.

6. Onurbaş Avcioğlu A., Türker U. 2012. Status and Potential of Biogas Energy From Animal Wastes in Turkey, Renewable and Sustainable Energy Reviews, 16 (2012): 1557-1561.

7. Haak L., Roy R., Pagilla K. 2015. Toxicity and Biogas Production Potential of Refinery Waste Sludge for Anaerobic Digestion, Chemosphere, 144 (2016): 1170-1176.

8. Diya'uddeen B.H., Daud W.M.A.W., Aziz A.R.A. 2011. Treatment Technologies for Petroleum Refinery Effluents: A Review, Process Safety and Environmental Protection, 89: 95-105.

9. Coates J.D., Anderson R.T., Woodward J.C., Phillips E.J., Lovley D.R., 1996. Anaerobic Hydrocarbon Degradation in Petroleum-contaminated Harbor Sediments Under Sulfate-reducing and Artificially Imposed Iron-reducing Conditions, Environmental Science \& Technology, 30 (9): 2784-2789.

10. Haritash A.K., Kaushik C.P., 2009. Biodegradation Aspects of Polycyclic Aromatic Hydrocarbons (PAHs): A Review, Journal of Hazardous Materials, 169 (1): 1-15.

11. Masten S.J., Davies S.H. 1997. Efficacy of In-situ for the Remediation of PAH Con-taminated Soils, Journal of Contaminant Hydrology, 28 (4): 327-335.

12. Gül N. 2006. Tavuk Gübresinden Biyogaz Üretim Potansiyelinin Araştırılması, Süleyman Demirel Üniversitesi, Fen Bilimleri Enstitüsü, Çevre Mühendisliği Anabilim Dalı, Yüksek Lisans Tezi, 57s, Isparta.

13. Koçar G., Eryaşar A., Ersöz Ö., Arıcı Ş., Durmuş A. 2010. Biyogaz Teknolojileri, Ege Üniversitesi Basımevi, İzmir.

14. Ojolo S.J., Oke S.A., Animasahun B.K., Adesuyi B.K. 2007. Utilization of Poultry, Cow and Kitchen Wastes for Biogas Production: A Comparative Analysis, Journal of Environmental Health Science \& Engineering, 4 (4): 223-228.

15. Çağlayan G.H., Koçer N.N. 2014. Muş İlinde Hayvan Potansiyelinin Değerlendirilerek Biyogaz Üretiminin Araştırılması, Muş Alparslan Üniversitesi Fen Bilimleri Dergisi, 2 (1): 215-220.

16. Okay B., Oktan P., Filiz, M., 1983. Biyogaz Tesisi Kullanma Rehberi, Türk Hükümeti-UNICEF Ortak Biyogaz Projesi T.C. Başbakanlık Devlet Planlama Teşkilatı Biyogaz Projesi Yayınları, Ankara.

17. Koca A. 2007. Yenilenebilir Bir Enerji Kaynağı: Biyogaz, Doğu Anadolu Bölgesi Araştırma Dergisi, 3: 129-137.

18. Myinta M, Nirmalakhandanb N, Speece R.E.2007. Anaerobic Fermentation of Cattle Manure: Modeling of Hydrolysis and Acidogenesis, Water Research, 4: 323-32.

19. Koçer N.N., Öner C., Sugözü İ. 2006. Türkiye'de Hayvancılı Potansiyeli ve Biyogaz Üretimi, Doğu Anadolu Bölgesi Araştırmaları, Türkiye.

20. İlci Tarım Hayvancılık San. ve Tic. A.Ş. 2010. http://www.ilcitarim.com.tr/index.php (Erişim tarihi: 26.04.2017). 
21. Enerji Günlüğ̈̈. 2016. http://www.enerjigunlugu.net/icerik/19663/ankaraya-6-mwlik-biyogazsantrali-kurulacak.html. (Erişim tarihi: 26.04.2017).

22. Enerji Enstitüsü. 2014. http://enerjienstitusu.com/2014/10/08/ankaranin-beypazari-ilcesindetavuk-gubresinden-elektrik-ureten-tesis-kuruldu/ (Erişim tarihi: 27.04.2017).

23. Enerji Gazetesi İst. 2016. http://www.enerjigazetesi.ist/ankaradaki-250-mwlik-biyogaz-tesisihalkin-gorusune-sunuldu/ (Erişim tarihi: 27.04.2017).

24. Karen Cacua K., Villalba L.O., Bernardo H., Gallego A. 2016. Experimental Evaluation of a Diesel-Biogas Dual Fuel Engine Operated on Micro-Trigeneration System for Power, Drying and Cooling, Applied Thermal Engineering, 100 (2016): 762-767.

25. Türkiye'de Atıklardan Enerji Üretimi ve Biyogaz. 2009. http://www.tarimsal.com/makaleler/Turkiye_Atiklardan_Enerji_uretimi_ve_biyogaz.htm (Erişim tarihi: 20.04.2017).

26. T.C. Çevre ve Şehircilik Bakanlığı. 2011. Suluova Biyogaz Tesisinin Teknik-Ekonomik Esaslarına İlişskin Rapor, Türk Alman Biyogaz Projesi, Ankara.

27. Aybek A., Üçok S., Bilgili M.E., İspir M.A. 2015. Kahramanmaraş İlinde Bazı Tarımsal Atıkların Biyogaz Enerji Potansiyelinin Belirlenerek Sayısal Haritalarının Oluşturulması, U.Ü. Ziraat Fakültesi Dergisi, 29 (2): 25-37.

28. Biyogaz Verimi. 2013. http://www.soleaenerji.com/biyogaz-verimi/ (Erişim tarihi: 28.04.2017).

29. Coğrafya Dünyas1. 2015. http://www.cografya.gen.tr/tr/ankara/ekonomi.html (Erişim tarihi: 22.04.2017).

30. T.C. Gıda Tarım ve Hayvancılık Bakanlığı. 2015. Ankara ili Tarımsal Yatırım Rehberi, Ankara.

31. TUiK Gida Tarım ve Hayvancılık Verileri. 2016. http://www.tuik.gov.tr/UstMenu.do?metod=temelist ( Erişim tarihi: 15.04.2017).

32. Dağ Ö. Ev Atıklarının Biyogaz Üretim Projesi. 2014. http://ozgurdag4941.blogspot.com.tr/2014/12/ev-atiklarindan-biyogaz-uretim-projesi.html?m=1 (Erişim tarihi: 01.05.2017).

33. Ankara Nüfusu. 2016. http://www.nufusu.com/il/ankara-nufusu (Erişim tarihi: 20.04.2017).

34. Ankara Büyükşehir Belediyesi. http://www.ankara.bel.tr/haberler/mamak-pl-dnyaya-modeloluyor/\#.WQb2vWnyjIU (Erişim tarihi: 02.03.2017).

35. Kaya D. 2010. Evsel Kaynakl Arıtma Çamurlarının Biyogaz Üretiminde Kullanımının Değerlendirilmesi, ICCI - Uluslararası Enerji ve Çevre Fuarı ve Konferansı, İstanbul.

36. Arıtma Çamurundan Biyogaz Üretimi ve Enerji Tasarrufu. https://www.yenienerji.info/proje/aritma-camurundan-biyogaz-uretimi-ve-enerji-tasarrufu (Erişim tarihi: 05.04.2017).

37. Yiğit K.S., Gündüz M., Şerit G., Yeğin M., Saraç M., Bayram İ., Bostan Ü., Pir H. 2011. Atıksu Arıtma Çamurundan Biyogaz Üretimi ve Enerji Tasarrufu, Kocaeli İZAYDAŞ ve İSU Çalışma Raporu, Türkiye.

38. ASKİ. http://www.aski.gov.tr/tr/icerik.aspx?id=817 ( Erişim tarihi: 22.04.2017).

39. Berkes F., Kışlalığlu M. B. 1993. Çevre ve Ekoloji, 4. Basım, Remzi Kitabevi, İstanbul.

40. Ilgar R. 2012. Hayvan Varlığına Göre Çanakkale Biyogaz Potansiyelinin Tespitine Yönelik Bir Çalışma, Doğu Coğrafya Dergisi, 35: 89-106.

41. EKSIS. Biyogaz Enerji Hesabı. http://www.kurutma.net/biogaz enerji hesabi.html (Erişim tarihi: 25.03.2017).

42. Ekonomik Yapı. 2005. https://www.ankara.bel.tr/files/2713/5056/3051/6-ekonomi.pdf (Erişim tarihi: 02.04.2017). 

43. Ankara $\quad \dot{\text { Ili }}$
http://www.emo.org.tr/ekler/9844ba129a1cbc3_ek.pdf (Erişim tarihi: 28.04.2017) 